\title{
The Global HIV Archive: Facilitating the Transition from Science to Practice of Efficacious HIV Prevention Interventions*
}

\author{
Josefina J. Card, Emily N. Newman, Rachel E. Golden, Tamara Kuhn, Carmela Lomonaco \\ Sociometrics Corporation, Los Altos, USA. \\ Email: jjcard@socio.com
}

Received December $14^{\text {th }}$, 2012; revised January $17^{\text {th }}$, 2013; accepted January $27^{\text {th }}$, 2013

\begin{abstract}
This paper describes the development, content, and capabilities of the online Global HIV Archive (GHA). With the goal of facilitating widespread adaptation and appropriate use of efficacious HIV prevention programs throughout the globe, GHA has: 1) expanded and updated the search for HIV prevention programs originating in low-resource countries; 2) identified those meritorious HIV prevention programs meeting established efficacy criteria of technical merit, replicability, and positive outcomes; 3 ) prepared both implementation and evaluation materials from the efficacious programs for public use; 4) developed interactive wizards or capacity-building tools to facilitate appropriate program selection, implementation, and adaptation; 5) made the efficacious programs and accompanying wizards available to health practitioners throughout the globe in both printed and online formats.
\end{abstract}

Keywords: HIV; Evidence-Based; Intervention; Prevention; Dissemination; International

\section{Introduction}

Despite promising developments in worldwide efforts to address HIV/AIDS, the number of people living with HIV continues to grow. According to the most recent UNAIDS Report on the Global AIDS Epidemic, between 2001 and 2011, the number of people living with HIV globally rose from 29.4 to 34 million. In 2011, an estimated 2.5 million adults and children were newly infected. More than $95 \%$ of people living with HIV/AIDS reside in the middle- and low-resource regions of the world. Sub-Saharan Africa, in particular, is home to more than two-thirds (69\%) of all infected adults and children. The majority of infections worldwide are transmitted heterosexually. In many regions, a significant proportion of infections occur among sex workers, men who have sex with men, and injection drug users [1]. Lack of access to quality HIV prevention programs for at-risk and vulnerable populations varies widely and contributes to the continuance of the epidemic in low-resource countries [2]. With twelve (12) new HIV infections for every six (6) individuals beginning an antiretroviral medication regimen that potentially prolongs life and prevents transmission, access to proven HIV prevention remains a

\footnotetext{
*The Global HIV Archive was produced with funds provided by the US National Institute of Mental Health under Grant R44MH082675-02A1 (Josefina J. Card, PhD, Principal Investigator).
}

pressing issue [3].

\subsection{Efficacious Behavioral Prevention Interventions Originating in Low-Resource Countries}

A large body of research has established the efficacy of behavioral interventions in changing individuals' risky sexual or injection-related behavior in the United States (US) [4-7]. Programs have been shown to change such behaviors among heterosexual adults [8-12]; men who have sex with men [13-16]; injection drug users [17,18]; young people [19]; and other high-risk populations [20-23]. Overall, the efficacious US-based intervention programs are theory-driven and culturally tailored and emphasize development of cognitive, social, and technical competencies associated with reducing risk [5,21,2427].

For many years, the dissemination of intervention information was limited to evaluation reports, literature reviews, or meta-analyses in journal articles and book chapters, sources not typically read by prevention practitioners $[28,29]$. However, recent advances in HIV prevention technology transfer-a process by which efficacious interventions are identified by researchers, translated for practitioner audiences, disseminated, and re-implemented [30-32] — are beginning to bridge the gap between research and practice $[31,33]$. The Centers for Disease 
Control and Prevention (CDC) has established Replicating Effective Programs (REP), a collection of replication kits for theory-based interventions with demonstrated efficacy in reducing HIV risk behaviors in the US [32,34]. CDC also provides training and technical assistance to support the implementation of evidence- based programs through the Diffusion of Effective Behavioral Interventions (DEBI) project [25,35,36]. Additionally, California-based Sociometrics Corporation, with funding from the US National Institutes of Health, has established the HIV/AIDS Prevention Program Archive (HAPPA) and the Program Archive on Sexuality, Health and Adolescence (PASHA). HAPPA and PASHA contain collections of several dozen program packages that include everything needed to replicate programs that have demonstrated efficacy in preventing HIV or its risk-re- lated behaviors among adults and youth in the US. They have facilitated access by health practitioners to efficacious programs and encouraged implementation and reevaluation of those programs at new sites $[30,37,38]$. As a result of the successful dissemination by Sociometrics, national scale-up efforts by CDC, and other efforts, the efficacious HIV prevention programs in HAPPA and PASHA are now being used in hundreds of sites around the US.

No similar resources to date have been created for health practitioners in the low-resource regions of the world, where the need for efficacious behavioral interventions is even greater. Indeed, efforts to synthesize information about HIV prevention programs that have been implemented and evaluated in low-resource country settings have only recently begun. Nonetheless, several reviews have identified programs that have shown positive results in reducing behavioral risks for HIV among youth [39-41] and adults [42-45]. Kirby and colleagues [40], for example, conducted a review focused on sex and HIV education programs for youth in both high- and low-resource countries that were based on written curricula and were implemented among groups in school, clinic, or community settings. The review identified 83 evaluations of curricula-based interventions for groups of youth, 18 of which were from low-resource countries. Likewise, Alford and colleagues [39] examined nearly 200 youth-focused programs in low-resource countries and identified 10 with evaluations that showed significant impact on sexual risk behaviors and sexual health outcomes.

Existing reviews also highlight some of the difficulties that health practitioners in low-resource countries face in identifying behavioral intervention programs and determining which of those might be efficacious for their populations and contexts. The initial aim of the CDC Prevention Research Synthesis (PRS) project, for example, was to analyze and synthesize the efficacy of US- based studies of HIV behavioral, social and policy interventions. In 1997, CDC expanded the scope of the PRS project to include studies conducted outside of the US. In a report summarizing PRS efforts to identify non-USbased studies, Eke and colleagues [42] noted that descriptions of HIV behavioral prevention studies in lowresource countries were not easily accessible through standard search strategies. Of the 1350 non-US-based studies ultimately reviewed by the PRS project, only 50 described behavioral interventions, of which 18 met the relevance and rigor criteria set by PRS. Likewise, a study conducted by Bollinger and colleagues [43] examined how HIV/AIDS prevention interventions in low-resource countries lead to behavioral change and how behavioral change leads to reductions in HIV prevalence. They conducted a systematic literature review of HIV/AIDS prevention interventions in low-resource countries and identified 186 studies that met their minimum criteria for study design and thus could be used to draw conclusions about the efficacy of the interventions. They noted, however, that the studies as a group suffered from methodological inadequacies including lack of or an inadequate control group, limited follow-up, high attrition, self-reported data, nonrandom allocation of study subjects, and lack of internal validity.

The considerable efforts in the US to identify efficacious HIV behavioral intervention programs, archive their materials, and make those materials available in readily usable formats to health practitioners provides a model for what could and should now be done for lowresource countries. The aforementioned reviews have collectively identified a group of studies that describe interventions with positive results in low-resource countries. They served as the starting point for the innovative resource forming the focus of the present paper, the Global HIV Archive (GHA). Funded by the US National Institute of Mental Health, GHA is: 1) expanding and updating the search for HIV prevention programs that have been implemented and evaluated in low-resource countries; 2) identifying those that meet established efficacy criteria; 3) archiving their materials for public use; and 4) making the materials available to health practitioners throughout the globe in both printed and online formats.

\subsection{Tools to Support Appropriate Program Implementation}

Behavioral HIV prevention translation research in the US, which focuses on development and validation of behavioral prevention programs in researcher-controlled conditions, has had many successes [46]. In particular, as indicated above, a number of prevention interventions for different target audiences in the US have shown positive 
effects in controlled efficacy trials. Translation research that addresses the efficacy and dissemination of those programs in practitioner-controlled "real world" settings in the US has been less prevalent or successful.

Practitioners and researchers have long recognized the importance of ensuring that programs address the cultural backgrounds and developmental levels of their target populations, as well as their agency and community contexts $[47,48]$. But US practitioners often experience difficulty determining how to adapt empirically-validated programs for their contexts [28,49]. The questions of when, what, and how to adapt are increasingly being addressed in the literature on HIV prevention and related fields [50-59]. There is general consensus that adaptation should maintain fidelity to the program's core components - defined as "those features in the intent and design of an intervention that are responsible for the efficacy of the intervention" [28, p. 90] while permitting flexibility to tailor non-core elements to new contexts. Methods for identifying core components have been proposed, but science-based, practitioner-focused tools to help practitioners apply the concepts of fidelity and flexibility to their work are lacking $[49,57]$. Modifications are made to adapt, alter or delete program content, scope and/or delivery method to accommodate for real-world circumstances (time constraints, varying population or setting needs or unavailability of organizational resources) and many are done without guidance for how these changes affect fidelity, core elements and desired outcomes [27, $60]$.

The lack of tools for practitioners in low-resource countries is an even greater issue. Once demonstrated efficacious behavioral intervention programs become available to health practitioners in low-resource countries, there is a considerable need for a program adaptation tool that will build their capacity to tailor the programs to diverse contexts. Without such a tool to guide them, practitioners may make changes to the core components that will limit the efficacy of their adaptations, or even have an undesired effect on target population behaviors. GHA addresses this gap by developing two versions of a Program Adaptation Toolkit: a customized version accompanying each GHA program package (developed in collaboration with the original program developer), as well as a stand-alone version for use with efficacious programs acquired elsewhere, such as from the original developer, from a federal agency, or from a commercial publisher. The GHA Program Adaptation Toolkit builds the user's capacity to adapt an empirically-validated program for the local context and target population.

When a number of empirically-validated behavioral intervention programs become known by health practi- tioners in low-resource countries, they will have choices as they consider how best to address their community's needs. Since those health practitioners may have limited access to scientific journals and evaluation reports, other vehicles are needed to provide information to help in choosing interventions that work in various contexts [50]. GHA has developed an online search tool that facilitates the identification and obtaining of additional information about the necessary resources to implement these validated behavioral interventions.

With increased emphasis on evidence-based intervenetions (EBIs), public health has sought to understand how setting and provider infrastructure and other capacityrelated factors both facilitate and challenge successful EBI implementation [61-63]. These capacity issues within organizations and across the prevention workforce have long been recognized by the World Health Organization (WHO), World Bank, the Gates Foundation and other NGOS, as a key area to strengthen the response to global health epidemics such as Avian bird flu; SARS; malaria; and HIV/AIDS [64]. Even the Millennium Goals identified improving programs through capacity building as a necessary component to fulfilling its goals [65].

Initiatives meant to scale up HIV prevention services in low-resource countries have recognized the complexity of program and service delivery and its associated challenges, including program management and oversight which tend to vary widely in each setting within and across country contexts [66]. The efforts to reinforce and build capacity in these countries are uneven; with some countries making strides and others falling behind $[67,68]$. Building workforce capacity in the context of HIV prevention is ongoing and at times, daunting with more resources and tools needed to strengthen systems, infrastructure and the workforce [63]. According to Theobald and colleagues [69], concentrated, resourceintensive efforts to increase capacity to provide services and implement programs have been and are underway in, for example, HIV in Kenya [70] and tuberculosis in Malawi [71] but the need is far greater than this approach can accommodate. Effective capacity-building resources that are practical, easily scalable, interactive and customizable are either not available or widely accessible. Moreover, science-based, practitioner-focused tools to help practitioners apply concepts such fidelity with a level of flexibility to program implementation are also lacking [49,57]. HIV prevention resources accessible through the web and mobile devices can increase opportunities for the dissemination of prevention and capacity building resources to practitioners in low-resource countries [50,72-77]. These combined resources help to bol- 
ster widespread dissemination of appropriate empiricallyvalidated interventions to new, practitioner-controlled service delivery sites.

In response to these needs, GHA has developed a set of tools and interactive smartphone and online wizards to support selection, implementation, and adaptation of efficacious HIV prevention interventions.

\section{Methods}

HAPPA and PASHA, the two successful collections of efficacious, US-based HIV and pregnancy prevention programs at Sociometrics, have used a systematic process to identify, review, and select programs for inclusion in the collections. The process ensures that: 1) each collection only includes efficacious programs proven by scientific methods to produce positive result(s) in HIVrelated outcomes; and 2) selected programs will be replicable in other settings and contexts. The GHA adapted this successful protocol in pulling together its collection of efficacious global HIV prevention programs. Figure 1 provides an outline of this process.

Step 1: Establishment of scientist expert panel

A select group of HIV prevention researchers with experience working in low-resource countries formed the

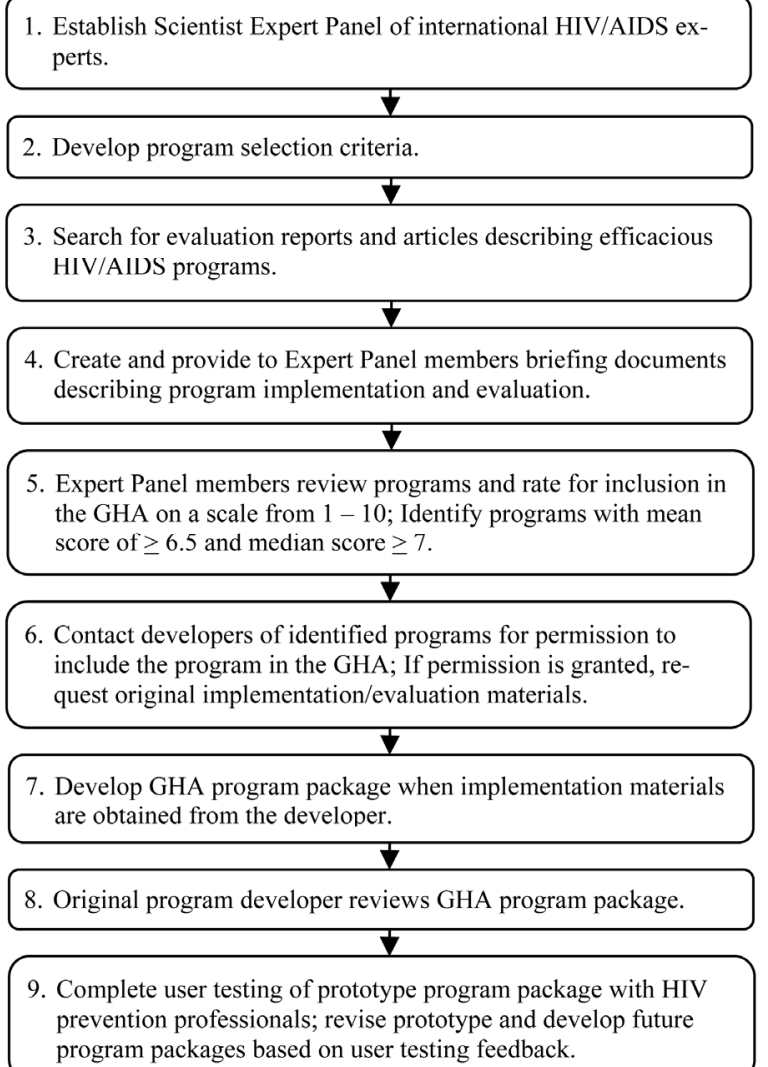

5. Expert Panel members review programs and rate for inclusion in the GHA on a scale from $1-10$; Identify programs with mean score of $\geq 6.5$ and median score $\geq 7$.

6. Contact developers of identified programs for permission to include the program in the GHA; If permission is granted, request original implementation/evaluation materials.

7. Develop GHA program package when implementation materials are obtained from the developer.

8. Original program developer reviews GHA program package.

9. Complete user testing of prototype program package with HIV prevention professionals; revise prototype and develop future program packages based on user testing feedback.

Figure 1. Process of program inclusion in the GHA.
GHA Scientist Expert Panel, tasked to review and select programs for inclusion in the collection. During the first round of program selections, in 2008, the panel members were: Dr. Don Des Jarlais (Beth Israel Medical Center, US); Dr. Seth Kalichman (University of Connecticut, US); Dr. Donald Morisky (University of California, Los Angeles, US); Dr. Susan Pick (Instituto Mexicano de Investigación de Familia y Población, Mexico); Dr. Quarraisha Abdool Karim (Columbia University, US); and Dr. Carlos Cáceres (Cayetano Heredia Peruvian University, Peru). A second selection round was conducted in 2010. Drs. Kalichman, Pick, and Abdool Karim stepped down from the panel this second round and were replaced by Dr. Jesse Mbwambo (Muhimbili University College of Health Sciences, Tanzania) and Dr. Suniti Solomon (Y.R. Gaitonde Center for AIDS Research and Education, India).

Step 2: Delineation of criteria for program efficacy

The selection criteria created for HAPPA, our archive of domestic HIV/AIDS prevention programs, served as a starting point for the development of the GHA's selection criteria. We revised the HAPPA selection criteria to reflect the unique challenges of implementing and evaluating programs in low-resource countries. Thus, the final selection criteria included less stringent follow-up time period requirements ( 3 months for the GHA, versus 6 months for HAPPA) while still meeting strict evaluation standards. Table 1 gives the GHA program selection criteria which were reviewed and approved by the Scientist Expert Panel at the outset of the project.

Step 3: Identification of candidate programs

To identify candidate programs for the GHA, we conducted extensive searches of relevant English language scientific literature, contacted international funding agencies and development organizations, and requested input from the Scientist Expert Panel. Specialized search strategies were also utilized, including the review of final reports to funding agencies, searches of international databases such as EMBASE (European medical citations), and the review of an international register compiled by the Cochrane Collaborative Review Group.

Step 4: Preparation of briefing materials on candidate programs

To facilitate the Expert Panel's review process, we then created briefing documents for each candidate program meeting the criteria in Table 1. These briefing documents provided a 4 - 6 page summary of the intervention (e.g., theoretical foundation, history, target population, content, and procedures) and the evaluation methods and findings. Expert Panel members were also provided with a copy of the scientific paper(s) or report(s) on which the summary was based. 
Table 1. Global HIV archive selection criteria.

1. Technical Merit: Scientifically rigorous evaluation with appropriate design and methods; comparison or control group; and follow-up assessment that occurred a minimum of three months after the end of the intervention.

2. Replicability: The ability of the program content to be widely disseminated across populations and settings.

3. Positive Outcomes: Demonstrated positive impact on one or more of the following HIV-related behaviors and/or HIV infection rates for one or more subgroups of persons:

\section{Sexual Risk Behaviors}

- Postponement of sexual intercourse

- Decreased frequency of sexual intercourse

- Decreased number of sexual partners

- Decreased frequency of sexual intercourse with partners who engage in high-risk behaviors (e.g., injection drug use, commercial sex work, male-male sex)

- $\quad$ Decreased number of HIV-risk sexual partners (e.g., injection drug users, commercial sex workers, gay and bisexual men)

- Increased use of effective HIV/AIDS prophylactics at first sexual contact

- Increased use of effective HIV/AIDS-prophylactic methods at most recent sexual contact

- Increased consistent use of effective HIV/AIDS-prophylactic methods at every sexual contact

- $\quad$ Substitution of lower-risk for higher-risk sexual behaviors

- Increased performance of other sex-related HIV/AIDS prevention behaviors (e.g., increased condom carrying)

- For HIV+ individuals, decreased sexual behaviors with HIV-or unknown HIV status partners

\section{Drug Injection Risk Behaviors}

- Abstinence from injection drug use

- Reduced frequency of injection drug use

- Increased seeking of drug abuse treatment

- Reduced sharing of drug injection equipment

- $\quad$ Reduced syringe-mediated drug sharing

- $\quad$ Reduced re-use of needles

- Increased use of sterile needles

- Increased disinfecting of needles

- Increased use of sterile water

Pre-and Perinatal Transmission Risk Behaviors

- Increased contraceptive use among HIV+ females

- Decreased pregnancy among HIV+ females

- Decreased births among HIV+ females

- Decreased births of HIV+ newborns

Antiretroviral Therapy (ART) adherence (Among HIV+ Persons)

- Increased ART adherence

\section{STI/HIV Infection Rates}

- Decreased STI/HIV infection rates

Viral Load (Among HIV+ Persons)

- Decreased viral load

Step 5: Selection of promising programs by scientist expert panel

Expert Panel members reviewed each candidate program's briefing document to decide on a priority score for the program's inclusion in the archive. Inclusion priority scores were allowed to range from 1 (low) to 10 (high). Panelists were instructed that scores ranging from 1 - 6 would indicate insufficient evidence of program efficacy and would be interpreted as "do not include in GHA”. In contrast, scores from 7 - 10 would indicate that the program had a satisfactory level evidence of efficacy and should thus be included in the GHA. Programs assigned a panel mean score $\geq 6.5$ and median score $\geq 7$ comprised the final set of programs selected for inclusion in the archive.

Step 6: Acquisition of selected programs

If a program passed the above Expert Panel selection process, we contacted the developer(s) and/or implementer(s) of the programs to obtain permission to include the program in the archive and to acquire the program's implementation and evaluation materials for public distribution by the GHA.

Step 7: Preparation of GHA program packages

We then packaged the program's implementation and evaluation materials in a user-friendly way to facilitate the program's “turn-key” implementation and cost-effective replication in a new setting, augmenting the provided information when helpful, in collaboration with the original developer. The resultant GHA "program package" or "replication kit" contains a complete set of implementation materials such as facilitator manuals, workbooks, handouts/worksheets and media resources such as videos or PowerPoint presentations. All GHA program packages contain a Customized Adaptation Handbook, a step-by-step guide to making adaptations to the program when resources, populations, settings and other contextual factors differ from the original program. GHA program packages also contain two program evaluation resources: 1) the original evaluation questionnaire(s) used to assess the program's efficacy; and 2) a generic Evaluation Resource Guide containing questionnaires, with strong psychometric properties, applicable to evaluating international HIV/AIDS programs’ efficacy.

Program materials, if obtained in a language other than English, were translated into the English language by a professional translator. All GHA program packages are available in English; if program materials were provided to GHA in another language, the original-language materials are also available as a supplement to the complete program package.

Due to the GHA's international target audience, replication kits may be downloaded from the GHA website, with file sizes decreased or limited at every opportunity to prevent lengthy download times for those connecting through low bit rate internet connections. GHA programs may be obtained electronically through cost-effective subscriptions and licenses allowing organizations to access and use more than one program at a time. Technical assistance is provided from Sociometrics with the pur- 
chase of any GHA program or subscription license. Comprehensive training either online, asynchronous, or faceto-face is also available for organizations needing additional implementation preparation.

Step 8: Review of GHA program packages by the original developer(s)

To ensure that we remained faithful to the original program through our interpretation and editing of program documents, the original program developers were asked to review the final GHA program package prior to announcement of the program's public availability. Developers were provided with their choice of a hard-copy box containing all programs and evaluation materials, or access to online program files to review. They provided written confirmation of their approval of the final GHA product.

Step 9: Usability testing of prototype

To ensure program packages were engaging, relevant, and user-friendly, the first prototype box was reviewed by thirty HIV prevention professionals working in different countries around the world. The prototype program package and subsequent program packages were revised or developed based on feedback received during usability testing. Suggested changes focused on simplifying "academic" language in program manuals, providing more implementation guidelines, re-formatting manuals to include more color and bullet points, adding examples of worksheets, and providing country-specific examples of adaptation strategies.

Step 10: Capacity-Building wizard creation

To increase users' capacity to successfully select, implement, and adapt efficacious HIV prevention programs in GHA, we created four online interactive "wizards" covering implementation challenges such as budget preparation, capacity self-assessment, dissemination of results of program implementation and evaluation, and adaptation of the program to a new setting or local context.

Step 11: Creation of a GHA website

We then created a GHA website housing both the GHA programs and interactive wizards. In creating the website we had the following goals and design criteria in mind: 1) increasing dissemination and implementation of the GHA programs by organizing the GHA contents in accordance with: best practices in web-design, recommendations stemming from an environmental scan of the HIV prevention field, and user testing of GHA prototypes; 2) supporting GHA-specific program implementation through the development of complementary capacity-building tools; 3) reaching a wide audience from various regions in the world, through implementation of simple navigation and minimal text, availability in multiple languages, and a mobile version of the site; and 4) building the site using scalable design and technological infrastructure for ease of future expansion.

\section{Results}

\subsection{The GHA Efficacious HIV Prevention Program Collection}

\subsubsection{Collaboration with the GHA Scientist Expert Panel}

Forty-two programs (21 in 2008 and 21 in 2010) were presented to the GHA Scientist Expert Panel for consideration for inclusion in GHA. Of these 42 programs, 23 (14 in 2008 and another 9 in 2010) were given scores indicating high priority for inclusion in GHA, based on the criteria described in Table 1: scientific merit of the evaluation, replicability of the program in other contexts, and positive outcomes. Table 2 provides a list and brief description of the 23 programs approved for inclusion in GHA. The program developer name(s), the country in which the program was found efficacious, and the average priority score assigned by the GHA Scientist Expert Panel are also given in Table 2. Table 2 shows that the highest average priority score assigned by the Scientist Expert Panel was 7.9. Reservations expressed by the Panel (reasons for not giving any program a score of 8,9 , or 10) focused primarily on: study methodology (insufficient sample size, over-reliance on self-reports, or clinical outcomes not assessed); replication or generalizability potential; effect size; and maintenance/sustainability of effects. Of the 23 programs approved for inclusion in GHA, 12 were originally developed for use in Africa (Angola, Cameroon, Kenya, Mozambique, Nigeria, South Africa, Tanzania, Trinidad, and Uganda) and 6 for use in Asia (China, Indonesia, and the Philippines). Fourteen had an American developer, working in collaboration with local implementers and HIV researchers.

\subsubsection{Collaboration with Developers of Selected Programs}

We attempted to contact all the developers of the 23 Panel-Selected programs in Table 2 to solicit their cooperation in making their program and evaluation materials available in polished form for public use. We were successful in obtaining the cooperation of 11 of these developers (the remaining 12 developers could not be reached, did not send program materials, or did not wish for the program to be included in the archive). Table 3 gives the ten programs whose program and evaluation materials are now part of GHA (the 11th program was deemed by project staff to be too "sexist" to include without major modification that threatened the integrity of the original program). Of the ten programs in GHA, the majority (six) are community-based; two are clinic 
Table 2. HIV prevention programs selected as "Effective" by scientist expert panel.

\begin{tabular}{|c|c|c|c|c|}
\hline Program Name & Country & Description & Mean Score & $\begin{array}{l}\text { Acquired } \\
\text { for GHA }\end{array}$ \\
\hline $\begin{array}{l}\text { 1. Primary School Action for } \\
\text { Better Health Program }\end{array}$ & Kenya & $\begin{array}{l}\text { Teachers and administrators from primary schools are } \\
\text { trained to incorporate sexual and reproductive health } \\
\text { education into school curricula and co-curricular } \\
\text { activities }[78,79] \text {. }\end{array}$ & 7.9 & $\checkmark$ \\
\hline $\begin{array}{l}\text { 2. HIV/AIDS and Alcohol } \\
\text { Risk Reduction } \\
\text { Counseling Intervention }\end{array}$ & South Africa & $\begin{array}{l}\text { STI clinic patients receive a behavioral risk reduction } \\
\text { counseling intervention addressing HIV risk, HIV } \\
\text { testing, motivation to change behaviors, and sexual } \\
\text { communication skill building [80-82]. }\end{array}$ & 7.8 & \\
\hline $\begin{array}{l}\text { 3. Intervention to Improve } \\
\text { Treatment-Seeking } \\
\text { Behavior and Prevent STIs } \\
\text { Among Nigerian Youth }\end{array}$ & Nigeria & $\begin{array}{l}\text { STI treatment-seeking behavior among youth is } \\
\text { addressed through peer education, public lectures, } \\
\text { health clubs in the schools, and training of STI } \\
\text { treatment providers [83]. }\end{array}$ & 7.8 & \\
\hline 4. Social Network Intervention & Bulgaria & $\begin{array}{l}\text { Leaders of Roma (gypsy) men's social networks } \\
\text { counsel members about STI/HIV risk reduction [84]. }\end{array}$ & 7.7 & \\
\hline $\begin{array}{l}\text { 5. Community-Based Sex } \\
\text { Education and Reproductive } \\
\text { Health Service Program }\end{array}$ & China & $\begin{array}{l}\text { Unmarried youth are provided counseling, through a } \\
\text { youth health counseling center, and services related to } \\
\text { sexuality and reproduction [85]. }\end{array}$ & 7.6 & \\
\hline 6. Nyeri Youth Health Project & Kenya & $\begin{array}{l}\text { Adult counselors are nominated by young people and } \\
\text { parents to provide youth with sexual and reproductive } \\
\text { health information and referrals for services during } \\
\text { organized activities. Counselors organize activities } \\
\text { such as discussion groups, role plays, and drama } \\
\text { performances with youth [86]. }\end{array}$ & 7.6 & \\
\hline $\begin{array}{l}\text { 7. Modified Directly Observed } \\
\text { Therapy (mDOT) Program }\end{array}$ & Mozambique & $\begin{array}{l}\text { This clinic-based program provides individuals living } \\
\text { with HIV directly observed therapy of HIV } \\
\text { medications through a peer supporter and } \\
\text { counseling/social support }[87,88] \text {. }\end{array}$ & 7.5 & $\checkmark$ \\
\hline 8. Entre Nous Jeunes Program & Cameroon & $\begin{array}{l}\text { Youth peer educators work in their community to } \\
\text { deliver reproductive and sexual health information, } \\
\text { distribute educational materials, and refer youth to } \\
\text { health services [89]. }\end{array}$ & 7.2 & $\checkmark$ \\
\hline 9. Mema Kwa Vijana Program & Tanzania & $\begin{array}{l}\text { This multifaceted adolescent sexual and reproductive } \\
\text { health program includes a set school curriculum } \\
\text { delivered to primary school students; provision of } \\
\text { youth friendly health services; community-based } \\
\text { condom and distribution by youth; and } \\
\text { community-wide activities [90-93]. }\end{array}$ & 7.2 & $\checkmark$ \\
\hline $\begin{array}{l}\text { 10. HIV/AIDS Warriors } \\
\text { Program }\end{array}$ & Angola & $\begin{array}{l}\text { Trained, local, civilian facilitators deliver five HIV } \\
\text { prevention sessions to groups of soldiers to increase } \\
\text { safer sex behaviors [94]. }\end{array}$ & 7.1 & $\checkmark$ \\
\hline 11. TeenSTAR Program & Chile & $\begin{array}{l}\text { The local clinic provides youth with pregnancy } \\
\text { prevention and STI services and information through } \\
\text { a curriculum about reproductive health, postponing } \\
\text { sex, gender issues, and drug/alcohol use }[95,96] \text {. }\end{array}$ & 7.1 & \\
\hline $\begin{array}{l}\text { 12. Peer Education for } \\
\text { Taxicab/ Tricycle Drivers }\end{array}$ & Philippines & $\begin{array}{l}\text { Peer educators deliver a community-based program } \\
\text { to increase knowledge of HIV/AIDS and positive } \\
\text { attitudes towards condom use among members of a } \\
\text { "bridge population" [97]. }\end{array}$ & 7.0 & $\checkmark$ \\
\hline $\begin{array}{l}\text { 13. Culturally Adapted } \\
\text { Intervention for Youth } \\
\text { Living with HIV }\end{array}$ & Uganda & $\begin{array}{l}\text { Nurses deliver a program focused on physical } \\
\text { health/nutrition, mental health, reducing HIV } \\
\text { transmission, and HIV stigma to youth living with } \\
\text { HIV in their homes and at a clinic [98, 99]. }\end{array}$ & 6.9 & \\
\hline $\begin{array}{l}\text { 14. Family AIDS Education } \\
\text { and Prevention Program } \\
\text { Through Imams }\end{array}$ & Uganda & $\begin{array}{l}\text { Imams and their assistants deliver HIV/AIDS } \\
\text { education to their community members and religious } \\
\text { groups [100]. }\end{array}$ & 6.5 & $\checkmark$ \\
\hline
\end{tabular}




\section{Continued}

\begin{tabular}{|c|c|c|c|c|}
\hline Program Name & Country & Description & Mean Score & Acquired for GHA \\
\hline $\begin{array}{l}\text { 15. Voluntary HIV Counseling } \\
\text { and Testing for } \\
\text { Individuals and Couples }\end{array}$ & $\begin{array}{l}\text { Kenya, Tanzania and } \\
\text { Trinidad }\end{array}$ & $\begin{array}{l}\text { Voluntary HIV counseling and testing (VCT) is provided to } \\
\text { individuals and partners to reduce unprotected sex } \\
{[101,102] \text {. }}\end{array}$ & 7.8 & \\
\hline $\begin{array}{l}\text { 16. Intervention with } \\
\text { Microfinance for AIDS } \\
\text { and Gender Equity } \\
\text { (IMAGE) Program }\end{array}$ & South Africa & $\begin{array}{l}\text { The program targets structural factors related to HIV } \\
\text { transmission including poverty, gender inequalities, and } \\
\text { intimate partner violence through a group-based } \\
\text { microfinance program and delivery of a gender and HIV } \\
\text { curriculum for women }[103,104] \text {. }\end{array}$ & 7.5 & $\checkmark$ \\
\hline 17. Bali STD/AIDS Study & Bali, Indonesia & $\begin{array}{l}\text { Female sex workers receive education about STIs and } \\
\text { testing and treatment for STIs. Condoms and printed } \\
\text { educational materials are also distributed among sex } \\
\text { workers and their clients }[105,106] \text {. }\end{array}$ & 7.3 & \\
\hline $\begin{array}{l}\text { 18. Voluntary Counseling and } \\
\text { Testing (VCT) Program }\end{array}$ & China & $\begin{array}{l}\text { Voluntary counseling and testing for STIs/HIV provided } \\
\text { for female sex workers [107]. }\end{array}$ & 7.3 & $\checkmark$ \\
\hline $\begin{array}{l}\text { 19. Community-based Directly } \\
\text { Observed Therapy (C-DOT) } \\
\text { Program }\end{array}$ & Lima, Peru & $\begin{array}{l}\text { Trained community members, "DOT Workers," visit } \\
\text { individuals living with HIV to monitor antiretroviral } \\
\text { medication doses, provide clinical and social support, } \\
\text { and accompany patients to outpatient appointments [108]. }\end{array}$ & 7.0 & $\checkmark$ \\
\hline $\begin{array}{l}\text { 20. Mujer Segura: Healthy } \\
\text { Woman }\end{array}$ & $\begin{array}{l}\text { Tijuana and Ciudad } \\
\text { Juarez, Mexico }\end{array}$ & $\begin{array}{l}\text { Trained staff and outreach workers deliver a brief } \\
\text { one-on-one motivational interviewing intervention to } \\
\text { female sex workers in order to increase condom use } \\
{[109,110] .}\end{array}$ & 7.0 & $\checkmark$ \\
\hline $\begin{array}{l}\text { 21. Sexual Risk Reduction } \\
\text { Program for Mexican Youth }\end{array}$ & Mexico & $\begin{array}{l}\text { Young people receive a six-hour safer sex program } \\
\text { addressing condom and contraceptive use, parent- } \\
\text { adolescent communication, and pregnancy } \\
\text { prevention [111]. }\end{array}$ & 6.9 & \\
\hline $\begin{array}{l}\text { 22. Behavior Change Program } \\
\text { for Injecting Drug Users }\end{array}$ & Sichuan, China & $\begin{array}{l}\text { A comprehensive HIV/AIDS intervention for urban drug } \\
\text { users (IDUs) combines information, education and } \\
\text { communication activities, peer education, VCT, condom } \\
\text { distribution, a needle-/syringe exchange, and methadone } \\
\text { maintenance therapy [112]. }\end{array}$ & 6.8 & \\
\hline $\begin{array}{l}\text { 23. HIV Prevention for Female } \\
\text { Sex Workers in Sichuan }\end{array}$ & Sichuan, China & $\begin{array}{l}\text { Female sex workers are provided with voluntary counseling } \\
\text { and testing services, needle exchanges, methadone } \\
\text { maintenance treatment, STI testing/treatment services, and } \\
\text { community-based support through seminars and publicity } \\
\text { events [113]. }\end{array}$ & 6.8 & \\
\hline
\end{tabular}

based; and one is school-based. Two are intended for use with HIV+ patients; two for use with sex workers; three for use with youth; and one for use with military personnel. The last column of Table $\mathbf{3}$ gives the training and implementation time required by each GHA program. Training time varies from none required to about 80 hours ("two 5-day sessions separated by a school term"). The variance in implementation time is even greater, with the shortest program (Mujer Segura, Healthy Woman) requiring but a single 35 minute session per client and the longest program (Mema kwa Vijana Program: Good Things for Young People) requiring a complex set of school, health services, and condom promotion activities over a 3-year period.

\subsection{The GHA Interactive Online Wizards}

Our literature review and environmental scan of gap ar- eas found that program implementers faced implementation challenges on the ground. We developed a set of online interactive capacity-building implementation tools to accompany GHA’s efficacious program collection.

\subsection{The GHA Interactive Online Wizards}

The Preparing Your Program Budget wizard was developed to help organizations build a budget specific to a selected Global HIV Archive program.

Information was obtained from each program developer about the specific costs associated with the program (e.g., the number and cost of obtaining enough condoms or other supplies needed to implement the program). This information was programmed into an infrastructure that accounts for users' planned staffing requirements, target population reach, resources required, and overhead expenses to build a tailored budget specific 
Table 3. Programs acquired and made part of the global HIV archive.

\begin{tabular}{|c|c|c|c|c|c|c|c|c|c|c|c|c|c|c|c|c|}
\hline \multirow[b]{2}{*}{$\begin{array}{l}\text { GHA Program } \\
\text { (Developer; Country) }\end{array}$} & \multicolumn{3}{|c|}{ Setting } & \multicolumn{6}{|c|}{ Target Population } & \multicolumn{6}{|c|}{ Global HIV Archive Category } & \multirow[b]{2}{*}{$\begin{array}{l}\text { Length of Training if } \\
\text { applicable, (T) Length } \\
\text { of Implementation, (I) }\end{array}$} \\
\hline & 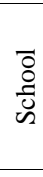 & 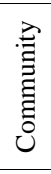 & 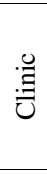 & 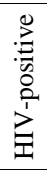 & 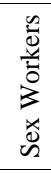 & 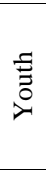 & 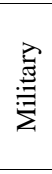 & 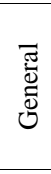 & 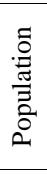 & 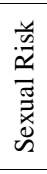 & 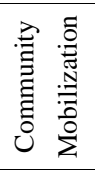 & 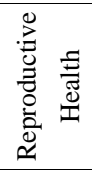 & 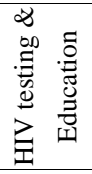 & 位导 & 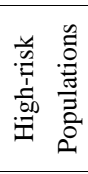 & \\
\hline $\begin{array}{l}\text { Community-Based } \\
\text { Directly Observed } \\
\text { Therapy (C-DOT) Program } \\
\text { (Sonya Shin, MD; Peru) }\end{array}$ & & $\mathrm{x}$ & & $\mathrm{X}$ & & & & & & & & & & $\mathrm{X}$ & $\mathrm{x}$ & $\begin{array}{l}\text { T: } 4 \text { days; I: } 11 \text { mos. } \\
\text { (daily visits for } 8 \text { mos., } \\
\text { tapered visits mos. } \\
9 \text { - 11) }\end{array}$ \\
\hline $\begin{array}{l}\text { Entre Nous Jeunes Program } \\
\text { (Gedeon Yomi, MsC; Cameroon) }\end{array}$ & & $\mathrm{x}$ & & & & $\mathrm{X}$ & & & & $\mathrm{X}$ & $\mathrm{x}$ & $\mathrm{x}$ & & & & $\begin{array}{l}\text { T: } 5 \text { days; I: } 18 \text { mos. } \\
\text { (no set schedule of } \\
\text { activities) }\end{array}$ \\
\hline $\begin{array}{l}\text { HIV/AIDS Warriors Program } \\
\text { (Daniel Ortiz, PhD; Angola) }\end{array}$ & & $\mathrm{X}$ & & & & & $\mathrm{x}$ & & & $\mathrm{X}$ & $\mathrm{x}$ & & & & $\mathrm{X}$ & $\begin{array}{l}\text { I: } 5 \text {, 4-hour sessions on } \\
\text { consecutive days; } \\
\text { 1-hour boosters } \\
\text { 2x/mos. for } 5 \text { mos. }\end{array}$ \\
\hline $\begin{array}{l}\text { Intervention with } \\
\text { Microfinance for } \\
\text { AIDS and Gender } \\
\text { Equity (IMAGE) } \\
\text { (RADAR; South Africa) }\end{array}$ & & $\mathrm{x}$ & & & & & & $\mathrm{X}$ & & $\mathrm{X}$ & $\mathrm{x}$ & & $\mathrm{x}$ & & & $\begin{array}{l}\text { T: 5-day workshop; } \\
\text { I: 1-hour sessions } \\
\text { every } 2 \text { weeks for } \\
1 \text { year }\end{array}$ \\
\hline $\begin{array}{l}\text { Mema kwa Vijana Program } \\
\text { (Good Things for Young People) } \\
\text { (National Institute for } \\
\text { Medical Research and } \\
\text { AMREF; Tanzania) }\end{array}$ & $\mathrm{x}$ & & & & & $\mathrm{X}$ & & & & $\mathrm{x}$ & $\mathrm{x}$ & $\mathrm{x}$ & & & & $\begin{array}{l}\text { I: } 12 \text {, } 40 \text {-min sessions } \\
\text { during } 1 \text { school year for } \\
3 \text { years; health services } \\
\text { and condom promotion } \\
\text { for } 3 \text { years; meetings } 6 \\
\text { days/year; } 1 \text {-week } \\
\text { health festival 1x/year; } \\
\text { health days } 2 \text { x/year; } \\
\text { video shows } 4 \text { x/year }\end{array}$ \\
\hline $\begin{array}{l}\text { Modified Directly Observed } \\
\text { Therapy (mDOT) Program } \\
\text { (Cynthia R. Pearson, } \\
\text { PhD; Mozambique) }\end{array}$ & & & $\mathrm{X}$ & $\mathrm{x}$ & & & & & & $\mathrm{x}$ & & & & $\mathrm{X}$ & & $\begin{array}{l}\mathrm{T}: 2,7 \text {, or } 10 \text { days; } \\
\text { 1-day refresher training } \\
\text { every } 3 \text { mos.; I: } 5 \\
\text { visits/week for } 6 \text { weeks }\end{array}$ \\
\hline $\begin{array}{l}\text { Mujer Segura, Healthy Woman } \\
\text { (Thomas L. Patterson, } \\
\text { PhD; Mexico) }\end{array}$ & & & $\mathrm{x}$ & & $\mathrm{x}$ & & & & & $\mathrm{x}$ & & & & & $\mathrm{X}$ & $\begin{array}{l}\mathrm{I}: 1,35 \text {-min session } \\
\text { (for } 1 \text { participant) }\end{array}$ \\
\hline $\begin{array}{l}\text { Peer Education Program } \\
\text { for Taxicab/Tricycle } \\
\text { Drivers and Other Bridge } \\
\text { Populations } \\
\text { (Donald E. Morisky, ScD, ScM, } \\
\text { MSPH; Philippines) }\end{array}$ & & $\mathrm{x}$ & & & & & & $\mathrm{X}$ & & $\mathrm{X}$ & & & & & $\mathrm{x}$ & $\begin{array}{l}\text { T: } 2 \text { days; I: } 1 \text { year }+ \\
\text { (no set schedule of } \\
\text { activities) }\end{array}$ \\
\hline $\begin{array}{l}\text { Primary School Action for } \\
\text { Better Health (PSABH) } \\
\text { (Janet Wildish, PhD } \\
\text { and Mary Gichuru, MA; Kenya) }\end{array}$ & $\mathrm{x}$ & & & & & $\mathrm{x}$ & & & & $\mathrm{X}$ & & $\mathrm{x}$ & & & & $\begin{array}{l}\text { T: 2, 5-day sessions } \\
\text { separated by a school } \\
\text { term; I: } 1 \text { school year+ }\end{array}$ \\
\hline $\begin{array}{l}\text { Voluntary Counseling } \\
\text { and Testing for } \\
\text { Female Sex Workers } \\
\text { (Xiaoming Li, PhD; China) }\end{array}$ & & $\mathrm{x}$ & & & $\mathrm{x}$ & & & & & $\mathrm{x}$ & & & $\mathrm{x}$ & & $\mathrm{x}$ & $\begin{array}{l}\text { T: } 3 \text { sessions totaling } \\
12.5 \text { - } 13.5 \text { hours on } 3 \\
\text { consecutive days; I: STI } \\
\text { exam/tests and pre-/ } \\
\text { post-test counseling } \\
\text { ( } 25 \text { mins. each over } 1 \\
\text { week, for } 1 \text { participant) }\end{array}$ \\
\hline
\end{tabular}


to the GHA program and implementation site.

The Know Your Capacity to Implement EvidenceBased Programs wizard was developed to help match an organization's capacity and priorities to specific Global HIV Archive programs. All GHA programs were categorized according to risk behavior addressed, target population, setting, and resources required. A database was created to organize programs according to these characteristics and suggest relevant programs based on a user's answers to questions about their organization's HIV prevention priorities and ability to implement identified programs based on funding, physical space, and other measures of capacity. The wizard provides the user with recommended programs as well as a summary regarding how this program matches their unique characteristics.

The Creating and Disseminating Results wizard teaches organizations how to interpret and communicate results of their program based on their intended audience. We designed this resource so that users first select their intended audience and identify what they hope to accomplish by sharing their "story" with the audience.

The Adaptation Handbook provides step-by-step instructions on how to make adaptations to programs while retaining features that are responsible, or are believed to be responsible, for the program's positive effects.

\subsection{The GHA Website}

A stand-alone website was built in English, Spanish and French to house the GHA's evidence-based program collection, the interactive capacity-building wizards, and a customized search function. The GHA website was designed to appeal to a global audience in both design and functionality. In developing the site, we fashioned the look and structure after NGO web sites that would be familiar to the intended audience, and created a simple navigation structure that features two distinct but complementary types of resources: program packages and capacity-building tools. The primary site navigation allows users to browse programs on the website based on their content area (sexual risk reduction, ART adherence, community mobilization, reproductive health, high-risk populations, and HIV testing and education), while the secondary navigation is by setting (community, clinic, or school). Users can also perform a full site search and identify programs based on keywords, titles, or developers. Each program on the site is fully described and has a multi-tabbed web page containing a short program description; list of program developers; image of one of the key program documents; a complete list of program characteristics such as implementation level, setting, and applicable populations; a list of program components; a complete list of the contents of the program package; and program-download links.

Once a program of interest has been identified on the GHA website, users with varying technological infrastructures can readily access digital copies of HIV prevention program packages. These packages contain all program materials in a format that can be viewed on the computer or printed, and any additional materials required for program implementation, such as videos or audio recordings. When available, users can also access supplementary materials in secondary languages including French, Spanish, Tagalog, Swahili, Portuguese, and Chinese.

The website was built to allow for expansion in both numbers of programs and/or additional capacity-building support. We developed a scalable, cloud-based infrastructure, allowing for nearly unlimited user and content growth. This infrastructure, along with the ability to integrate into existing NGOs' efforts in implementing HIV prevention services across a variety of constituencies, allows the site and programs to be made available in a variety of ways, for example, to a single individual, a single organization, a consortium of organizations, or even across an entire country based on site users' needs.

\section{Discussion}

The GHA is a resource that utilizes both science and technology in meeting the needs of frontline HIV prevention practitioners. To have impact in the real-world, a resource needs to be based on the latest scientific knowledge, duly translated into language and formats accessible to global workers trying to stem the epidemic. The GHA exhibits several innovations in prevention programming all aimed at facilitating real-world impact: development of replication kits for global prevention programs that science has found to be efficacious; provision of replication kits in both the original language used by the program and in the universal language English; digitization of all replication kits to facilitate global access via the Internet; provision of tools for science-based program adaptation to a new context; provision of interactive online wizards to develop HIV practitioners' program selection and implementation capabilities; provision of the original evaluation instrument that was used to demonstrate the program's efficacy, to encourage re-evaluation of the efficacious program in a new setting; creation of a website (in English, Spanish, and French) dedicated solely to dissemination of the GHA innovations; and building into the GHA website both scalable design and a technological infrastructure for ease of future expansion, as other efficacious HIV prevention programs are identified.

For the GHA to be maximally effective, it is important 
that technical assistance and training accompany its science-based resources (efficacious programs, capacitybuilding tools/wizards). To this end, free technical assistance is offered by GHA staff to all users of GHA resources. Additional training, both in-person and via webinars and web-based videoconferences, is also offered ${ }^{1}$.

\section{REFERENCES}

[1] UNAIDS, “Global Report: UNAIDS Report on the Global AIDS Epidemic,” 2012.

http://www.unaids.org/en/media/unaids/contentassets/doc uments/epidemiology/2012/gr2012/20121120_UNAIDS_ Global_Report_2012_en.pdf

[2] World Health Organization (WHO), "Global Health Sector Strategy on HIV/AIDS 2011-2015,” 2011. http://www.who.int/hiv/pub/hiv_strategy/en/index.html

[3] UNAIDS, “Global Report: UNAIDS Report on the Global AIDS Epidemic,” 2010. http://www.unaids.org/globalreport/global_report.htm

[4] Centers for Disease Control and Prevention (CDC), "Compendium of HIV Prevention Interventions with Evidence of Effectiveness,” 2008.

http://www.cdc.gov/hiv/topics/research/prs/evidence-base d-interventions.htm

[5] J. A. Kelly and S. C. Kalichman, "Behavioral Research in HIV/AIDS Primary and Secondary Prevention: Recent Advances and Future Directions," Journal of Consulting and Clinical Psychology, Vol. 70, No. 3, 2002, pp. 626639. doi:10.1037/0022-006X.70.3.626

[6] C. M. Lyles, L. S. Kay, N. Crepaz, J. H. Herbst, W. F. Passin, A. S. Kim, S. M. Rama, S. Thadiparthi, J. B. DeLuca and M. M. Mullins, "Best-Evidence Interventions: Findings from a Systematic Review of HIV Behavioral Interventions for US Populations at High Risk, 20002004,” American Journal of Public Health, Vol. 97, No. 1, 2007, pp. 133-143. doi:10.2105/AJPH.2005.076182

[7] S. M. Noar, "Behavioral Interventions to Reduce HIVRelated Sexual Risk Behavior: Review and Synthesis of Meta-Analytic Evidence,” AIDS and Behavior, Vol. 13, No. 3, 2008, pp. 335-353.

[8] L. Darbes, N. Crepaz, C. Lyles, G. Kennedy and G. Rutherford, "The Efficacy of Behavioral Interventions in Reducing HIV Risk Behaviors and Incident Sexually Transmitted Diseases in heterosexual African Americans,” AIDS, Vol. 22, No. 10, 2008, pp. 1177-1194. doi:10.1097/QAD.0b013e3282ff624e

[9] T. M. Exner, D. W. Seal and A. A. Ehrhardt, "A Review of Interventions for at-Risk Women," AIDS and Behavior, Vol. 1, No. 2, 1999, pp. 93-124.

[10] M. S. Neumann, W. D. Johnson, S. Semaan, S. A. Flores, G. Peersman, L. V. Hedges and E. Sogolow, "Review and Meta-Analysis of HIV Prevention Intervention Research for Heterosexual Adult Populations in the United States," Journal of Acquired Immune Deficiency Syndromes, Vol.

${ }^{1}$ Email Dr. J. J. Card at jjcard@socio.com or Dr. Carmela Lomonaco at lomoncao@socio.com.
30, No. 1, 2002, pp. S106-S117. doi:10.1097/00126334-200207011-00010

[11] T. K. Logan, J. Cole and C. Leukefeld, "Women, Sex, and HIV: Social and Contextual Factors, Meta-Analysis of Published Interventions, and Implications for Practice and Research,” Psychological Bulletin, Vol. 128, No. 6, 2002, pp. 851-885. doi:10.1037/0033-2909.128.6.851

[12] S. J. S. Mize, B. E. Robinson, W. O. Bockting and K. E. Scheltema, "Meta-Analysis of the Effectiveness of HIV Prevention Interventions for Women," AIDS Care, Vol. 14, No. 2, 2002, pp. 163-180. doi:10.1080/09540120220104686

[13] J. H. Herbst, R. T. Sherba, N. Crepaz, J. B. Deluca, L. Zohrabyan, R. D. Stall and C. M. Lyles, "A Meta-Analytic Review of HIV Behavioral Interventions for Reducing Sexual Risk Behavior of Men Who Have Sex with Men," Journal of Acquired Immune Deficiency Syndromes, Vol. 39, No. 2, 2005, pp. 228-241.

[14] W. D. Johnson, L. V. Hedges and R. M. Diaz, "Interventions to Modify Sexual Risk Behaviors for Preventing HIV Infection in Men Who Have Sex with Men," Cochrane Database of Systematic Reviews, Vol. 1, 2007, pp. $1-18$.

[15] W. D. Johnson, R. M. Diaz, W. D. Flanders, M. Goodman, A. N. Hill, D. Holtgrave, R. Malow and W. M. McClellan, "Behavioral Interventions to Reduce Risk for Sexual Transmission of HIV among Men Who Have Sex with Men," Cochrane Database of Systematic Reviews, Vol. 3, 2008.

[16] J. H. Herbst, C. Beeker, A. Mathew, T. McNally, W. F. Passin, L. S. Kay, N. Crepaz, C. M. Lyles, P. Briss, S. Chattopadhyay and R. L. Johnson, "The Effectiveness of Individual-, Group-, and Community-Level HIV Behavioral Risk-Reduction Interventions for Adult Men Who Have Sex With Men: A Systematic Review," American Journal of Preventive Medicine, Vol. 32, No. 4, 2007, pp. 38-67. doi:10.1016/j.amepre.2006.12.006

[17] D. S. Metzger and H. A. Navaline, "HIV Prevention among Injection Drug Users: The Need for Integrated Models,” Journal of Urban Health, Vol. 80, No. 4, 2003, pp. 59-64.

[18] M. M. Copenhaver, B. T. Johnson, I.-C. Lee, J. J. Harman and M. P. Carey, "Behavioral HIV Risk Reduction among People Who Inject Drugs: Meta-Analytic Evidence of Efficacy,” Journal of Substance Abuse Treatment, Vol. 31, No. 2, 2006, pp. 163-171. doi:10.1016/j.jsat.2006.04.002

[19] L. Robin, P. Dittus, D. Whitaker, R. Crosby, K. Ethier, J. Mezoff, K. Miller and K. Pappas-Deluca, "Behavioral Interventions to Reduce Incidence of HIV, STD, and Pregnancy among Adolescents: A Decade in Review," Journal of Adolescent Health, Vol. 34, No. 1, 2004, pp. 3-26. doi:10.1016/S1054-139X(03)00244-1

[20] M. P. Carey, K. B. Carey, S. A. Maisto, C. M. Gordon, K. E. E. Schroder and P. A. Vanable, " Reducing HIV-Risk Behavior among Adults Receiving Outpatient Psychiatric Treatment: Results from a Randomized Controlled Trial," Journal of Consulting and Clinical Psychology, Vol. 72, No. 2, 2004, pp. 252-268. 
doi:10.1037/0022-006X.72.2.252

[21] N. Crepaz, A. K. Horn, S. M. Rama, T. Griffin, J. B. Deluca, M. M. Mullins and S. O. Aral, "The Efficacy of Behavioral Interventions in Reducing HIV Risk Sex Behaviors and Incident Sexually Transmitted Disease in Black and Hispanic Sexually Transmitted Disease Clinic Patients in the United States: A Meta-Analytic Review," Sexually Transmitted Diseases, Vol. 34, No. 6, 2007, pp. 319-332.

[22] T. E. Senn and M. P. Carey, "HIV, STD, and Sexual Risk Reduction for Individuals with a Severe Mental Illness: Review of the Intervention Literature," Current Psychiatry Reviews, Vol. 4, No 2, 2008, pp. 87-100. doi:10.2174/157340008784529313

[23] D. J. Ward, B. Rowe, H. Pattison, R. S. Taylor and K. W. Radcliffe, "Reducing the Risk of Sexually Transmitted Infections in Genitourinary Medicine Clinic Patients: A Systematic Review and Meta-Analysis of Behavioral Interventions," Sexually Transmitted Infections, Vol. 81, No. 5, 2005, pp. 386-393. doi:10.1136/sti.2004.013714

[24] R. J. DiClemente, G. M. Wingood, C. Del Rio and R. A. Crosby, "Prevention Interventions for HIV Positive Individuals,” Sexually Transmitted Infections, Vol. 78, No. 6, 2002, pp. 393-395. doi:10.1136/sti.78.6.393

[25] J. S. Galbraith, J. H. Herbst, D. K. Whittier, P. L. Jones, B. D. Smith, G. Uhl and H. H. Fisher, "Taxonomy for Strengthening the Identification of Core Elements for Evidence-Based Behavioral Interventions for HIV/AIDS Prevention," Health Education Research, Vol. 26, No. 5, 2011, pp. 872-885. doi:10.1093/her/cyr030

[26] J. H. Herbst, L. S. Kay, W. F. Passin, C. M. Lyles, N. Crepaz and B. V. Marin, "A Systematic Review and Meta-Analysis of Behavioral Interventions to Reduce HIV Risk Behaviors of Hispanics in the United States and Puerto Rico,” AIDS and Behavior, Vol. 11, No. 1, 2007, pp. 25-47. doi:10.1007/s10461-006-9151-1

[27] M. J. Rotheram-Borus, D. Swendeman, D. Flannery, E. Rice, D. M. Adamson and B. Ingram, "Common Factors in Effective HIV Prevention Programs," AIDS and Behavior, Vol. 13, No. 3, 2009, pp. 399-408. doi:10.1007/s10461-009-9531-4

[28] J. A. Kelly, T. G. Heckman, L. Y. Stevenson, P. N. Williams, T. Ertl, R. B. Hays, N. R. Leonard, L. O’Donnell, M. A. Terry, E. D. Sogolow and M. S. Neumann, "Transfer of Research-Based HIV Prevention Interventions to Community Service Providers: Fidelity and Adaptation," AIDS Education and Prevention, Vol. 12, No. S5, 2000, pp. 87-98.

[29] J. J. Card, "The Sociometrics Program Archives: Promoting the Dissemination of Evidence-Based Practices through Replication Kits," Research on Social Work Practice, Vol. 11, No. 4, 2001, pp. 521-526. doi:10.1177/104973150101100407

[30] J. J. Card, T. Benner, J. P. Shields and N. Feinstein, “The HIV/AIDS Prevention Program Archive (HAPPA): A Collection of Promising Prevention Programs in a Box," AIDS Education and Prevention, Vol. 13, No. 1, 2001, pp. 1-28. doi:10.1521/aeap.13.1.1.18926
[31] A. N. Eke, M. S. Neumann, A. L. Wilkes and P. L. Jones, "Preparing Effective Behavioral Interventions to Be Used by Prevention Providers: The Role of Researchers During HIV Prevention Research Trials,” AIDS Education and Prevention, Vol. 18, No. 4, 2006, pp. 44-58.

[32] M. S. Neumann and E. D. Sogolow, "Replicating Effective Programs: HIV/AIDS Prevention Technology Transfer," AIDS Education and Prevention, Vol. 12, No. S5, 2000, pp. 35-48.

[33] Institute of Medicine, Committee on HIV Prevention Strategies in the United States, "No Time to Lose: Getting More from HIV Prevention," National Academy Press, Washington DC, 2001.

[34] Centers for Disease Control and Prevention (CDC), "Replicating Effective Programs Plus,” 2008. http://www.cdc.gov/hiv/topics/prev_prog/rep/index.htm

[35] Centers for Disease Control and Prevention (CDC), "Diffusion of Effective Behavioral Interventions (DEBI)," 2008. http://www.effectiveinterventions.org

[36] C. Collins, C. Harshbarger, R. Sawyer and M. Hamdallah, "The Diffusion of Effective Behavioral Interventions Project: Development, Implementation, and Lessons Learned," AIDS Education and Prevention, Vol. 18, No. 4, 2006, pp. 5-20.

[37] J. J. Card, S. Niego, A. Mallari and W. S. Farrell, “The Program Archive on Sexuality Health \& Adolescence: Promising Prevention Programs in a Box," Family Planning Perspectives, Vol. 28, No. 5, 1996, pp. 210-220. doi: $10.2307 / 2135840$

[38] J. J. Card, L. Lessard and T. Benner, "PASHA: Facilitating the Replication and Use of Effective Adolescent Pregnancy and STI/HIV Prevention Programs," Journal of Adolescent Health, Vol. 40, No. 3, 2007, pp. e1-e14.

[39] S. Alford, N. Cheetham and D. Hauser, "Science \& Success in Developing Countries: Holistic Programs that Work to Prevent Teen Pregnancy, HIV \& Sexually Transmitted Infections," Advocates for Youth, Washington, 2005.

[40] D. Kirby, B. A. Laris and L. Rolleri, "Impact of Sex and HIV Education Programs on Sexual Behaviors of Youth in Developing and Developed Countries,” Family Health International, Research Triangle Park, North Carolina, 2005.

[41] V. A. Paul-Ebhohimhen, A. Poobalan and E. R. van Teijlingen, "A Systematic Review of School-Based Sexual Health Interventions to Prevent STI/HIV in Sub-Saharan Africa,” BMC Public Health, Vol. 8, No. 4, 2008.

[42] A. Eke, G. Peersman, S. Semaan, K. Hylton, N. Kiiti and M. Sweat, "Acquisition and Review of Non-US-Based HIV Risk Reduction Intervention Studies," Journal of Acquired Immune Deficiency Syndromes, Vol. 30, No. 1, 2002, pp. 51-55. doi:10.1097/00042560-200207011-00005

[43] L. Bollinger, K. Cooper-Arnold and J. Stover, "Where Are the Gaps? The Effects of HIV-Prevention Interventions on Behavioral Change," Studies in Family Planning, Vol. 35, No. 1, 2004, pp. 27-38. 
doi:10.1111/j.1728-4465.2004.00003.x

[44] M. Shahmanesh, V. Patel, D. Mabey and F. Cowan, "Effectiveness of Interventions for the Prevention of HIV and Other Sexually Transmitted Infections in Female Sex Workers in Resource Poor Setting: A Systematic Review," Tropical Medicine and International Health, Vol. 13, No. 5, 2008, pp. 659-679. doi:10.1111/j.1365-3156.2008.02040.X

[45] Y. Hong and X. M. Li, "HIV/AIDS Behavioral Interventions in China: A Literature Review and Recommendation for Future Research,” AIDS and Behavior, Vol. 13, No. 3, 2009, pp. 603-613. doi:10.1007/s10461-008-9483-0

[46] S. Sussman, T. W. Valente, L. A. Rohrbach, S. Skara and M. A. Pentz, "Translation in the Health Professions: Converting Science into Action," Evaluation and the Health Professions, Vol. 29, No. 1, 2006, pp. 7-32. doi:10.1177/0163278705284441

[47] J. G. Dévieux, R. M. Malow, R. Rosenberg and J. G. Dyer, "Context and Common Ground: Cultural Adaptation of an Intervention for Minority HIV Infected Individuals,” Journal of Cultural Diversity, Vol. 11, No. 2, 2004, pp. 49-57.

[48] P. Vinh-Thomas, M. M. Bunch and J. J. Card, “A Research-Based Tool for Identifying and Strengthening Culturally Competent and Evaluation-Ready HIV/AIDS Prevention Programs," AIDS Education and Prevention, Vol. 15, No. 6, 2003, pp. 481-498. doi:10.1521/aeap.15.7.481.24050

[49] A. Gandelman and C. A. Rietmeijer, "Translation, Adaptation, and Synthesis of Interventions for Persons Living with HIV: Lessons from Previous HIV Prevention Interventions," Journal of Acquired Immune Deficiency Syndromes, Vol. 37, No. S2, 2004, pp. S126-S129. doi:10.1097/01.qai.0000140612.89757.8a

[50] J. A. Kelly, E. D. Sogolow and M. S. Neumann, "Future Directions and Emerging Issues in Technology Transfer between HIV Prevention Researchers and CommunityBased Service Providers," AIDS Education and Prevention, Vol. 12, No. S5, 2000, pp. 126-141.

[51] M. G. Kennedy, Y. Mizuno, R. Hoffman, C. Baume and J. Strand, "The Effect of Tailoring a Model HIV Prevention Program for Local Adolescent Target Audiences,” AIDS Education and Prevention, Vol. 12, No. 3, 2000, pp. 225-238.

[52] J. M. Kraft, J. S. Mezoff, E. D. Sogolow, M. S. Neumann and P. A. Thomas, "A Technology Transfer Model for Effective HIV/AIDS Interventions: Science and Practice," AIDS Education and Prevention, Vol. 12, No. S5, 2000, pp. 7-20.

[53] V. S. McKleroy, J. S. Galbraith, B. Cummings, P. Jones, C. Harshbarger, C. Collins, D. Gelaude, J. W. Carey and the ADAPT Team, "Adapting Evidence-Based Interventions for New Settings and Target Populations," AIDS Education and Prevention, Vol. 18, No. 1, 2006, pp. 5973. doi:10.1521/aeap.2006.18.supp.59

[54] M. J. Rotheram-Borus, B. L. Ingram, D. Swendeman and
D. Flannery, “Common Principles Embedded in Effective Adolescent HIV Prevention Programs," AIDS and Behavior, Vol. 13, No. 3, 2009, pp. 387-398. doi:10.1007/s10461-009-9531-4

[55] B. Stanton, J. Guo, L. Cottrell, J. Galbraith, X. M. Li, C. Gibson, R. Pack, M. Cole, S. Marshall and C. Harris, "The Complex Business of Adapting Effective Interventions to New Populations: An Urban to Rural Transfer," Journal of Adolescent Health, Vol. 37, No. 2, 2005, p. 163.

[56] S. R. Tortolero, C. M. Markham, G. S. Parcel, R. J. Peters Jr., S. L. Escobar-Chaves, K. Basen-Engquist and H. L. Lewis, "Using Intervention Mapping to Adapt an Effective HIV, Sexually Transmitted Disease, and Pregnancy Prevention Program for High-Risk Minority Youth," Health Promotion Practice, Vol. 6, No. 3, 2005, pp. 286-298. doi:10.1177/1524839904266472

[57] J. Solomon, J. J. Card and R. M. Malow, “Adapting Efficacious Interventions: Advancing Translational Research in HIV Prevention," Evaluation and the Health Professions, Vol. 29, No. 2, 2006, pp. 162-194. doi:10.1177/0163278706287344

[58] M. L. Wainberg, K. McKinnon, P. E. Mattos, D. Pinto, C. G. Mann, C. S. de Oliveira, S. B. de Oliveira, R. H. Remien, K. S. Elkington and F. Cournos, "A Model for Adapting Evidence-Based Behavioral Interventions to a New Culture: HIV Prevention for Psychiatric Patients in Rio de Janeiro, Brazil,” AIDS and Behavior, Vol. 11, No. 6, 2007, pp. 872-883. doi:10.1007/s10461-006-9181-8

[59] G. Wingood and R. DiClemente, "The ADAPT-ITT Model: A Novel Method of Adapting Evidence-Based HIV Interventions,” Journal of Acquired Immune Deficiency Syndromes, Vol. 47, No. S1, 2008, pp. S40-S46. doi:10.1097/QAI.0b013e3181605df1

[60] J. S. Galbraith, B. Stanton, B. Boekeloo, W. King, S. Desmond, D. Howard, M. M. Black and J. W. Carey, "Exploring Implementation and Fidelity of EvidenceBased Behavioral Interventions for HIV Prevention: Lessons Learned from the Focus on Kids Diffusion Case Study," Health Education and Behavior, Vol. 36, No. 3, 2009, pp. 532-549. doi:10.1177/1090198108315366

[61] R. S. Beidas and P. C. Kendall, "Training Therapists in Evidence-Based Practice: A Critical Review of Studies from a Systems-Contextual Perspective," Clinical Psychology: Science and Practice, Vol. 17, No. 1, 2010, pp. 1-30.

[62] S. Bharat and V. S. Mahendra, "Meeting the Sexual and Reproductive Health Needs of People Living with HIV: Challenges for Health Care Providers," Reproductive Health Matters,” Vol. 15, No. S29, 2007, pp. 93-112. doi:10.1016/S0968-8080(07)29030-5

[63] D. L. Richter, L. H. Potts, M. S. Prince, K. N. Dauner, B. M. Reininger, M. Thompson-Robinson, S. J. Corwin, C. Getty and R. Jones, "Development of a Curriculum to Enhance Community-Based Organizations' Capacity for Effective HIV Prevention Programming and Management," AIDS Education and Prevention, Vol. 18, No. 4, 2006, pp. 362-374. doi:10.1521/aeap.2006.18.4.362 
[64] G. Rodier, A. L. Greenspan, J. M. Hughes and D. L. Heymann, "Global Public Health Security,” Emerging Infectious Diseases, Vol. 13, No. 10, 2007, pp. 1447-1452. doi:10.3201/eid1013.070732

[65] D. Shaw, "Women's Right to Health and the Millennium Development Goals: Promoting Partnerships to Improve Access," International Journal of Gynecology and Obstetrics, Vol. 94, No. 3, 2006, pp. 207-215. doi:10.1016/j.ijgo.2006.04.029

[66] World Health Organization (WHO), "Scaling-Up HIV Testing and Counseling Services: A Toolkit for Programme Managers,” Geneva, 2005.

[67] UNAIDS/WHO, “AIDS epidemic outlook,” Geneva, 2009.

[68] World Health Organization (WHO), Maximizing Positive Synergies Collaborative Group (MPSCG), “An Assessment of Interactions between Global Health Initiatives and Country Health Systems," Lancet, Vol. 373, No. 9681, 2009, pp. 2137-2169. doi:10.1016/S0140-6736(09)60919-3

[69] S. Theobald, M. Taegtmeyer, S. B. Squire, J. Crichton, B. N. Simwaka, R. Thomson, I. Makwiza, R. Tolhurst, T. Martineau and I. Bates, "Towards Building Equitable Health Systems in Sub-Saharan Africa: Lessons from Case Studies on Operational Research," Health Research Policy and Systems, Vol. 7, No. 26, 2009.

[70] E. Marum, M. Taegtmeyer and K. Chebet, "Scale-Up of Voluntary HIV Counseling and Testing in Kenya," The Journal of the American Medical Association, Vol. 296, No. 7, 2006, pp. 859-862. doi:10.1001/jama.296.7.859

[71] B. N. Simwaka, "Strengthening the Skills and Capacity of the Informal Community Health System to Increase Early Access to Tuberculosis Services for Poor Men and Women: The Case of the Extending Services to Communities in Urban Lilongwe, Malawi,” Ph.D. Dissertation, Liverpool School of Tropical Medicine, University of Liverpool UK, Liverpool, 2007.

[72] S. Bertozzi, N. S. Padian, J. Wegbreit, L. M. DeMaria, B. Feldman, H. Gayle, J. Gold, R. Grant and M. T. Isbell, "HIV/AIDS Prevention and Treatment: In Disease Control Priorities in Developing Countries," 2nd Edition, Oxford University Press, Oxford, 2006.

[73] A. Farel, K. Umble and B. Polhamos, "Impact of an Online Analytic Skills Course,” Evaluation and the Health Professions, Vol. 24, No. 4, 2001, pp. 446-459. doi:10.1177/01632780122035019

[74] A. M. Farel, S. E. Pfau, S. C. Paliulis and K. E. Umble, "Online Analytic and Technical Training," Journal of Public Health Management and Practice, Vol. 9, No. 6, 2003, pp. 513-521.

[75] M. J. Fotheringham, D. Owies, E. Leslie and N. Owen, "Interactive Health Communication in Preventive Medicine: Internet-Based Strategies in Teaching and Research," American Journal of Preventive Medicine, Vol. 19, No. 2, 2000, pp. 113-120. doi:10.1016/S0749-3797(00)00188-4

[76] K. E. Umble, R. M. Cervero, B. Yang and W. L. Atkinson, "Effects of Traditional Classroom and Distance Con- tinuing Education: A Theory-Driven Evaluation of a Vaccine-Preventable Diseases Course," American Journal of Public Health, Vol. 90, No. 8, 2000, pp. 1218-1224. doi:10.2105/AJPH.90.8.1218

[77] R. D. Waddell and R. P. Kulig, "Webcasting: An Innovative Approach to HIV/AIDS Professional Training in a Rural Setting," Journal of HIV/AIDS \& Social Services, Vol. 4, No. 2, 2005, pp. 45-55. doi:10.1300/J187v04n02_05

[78] E. Maticka-Tyndale, C. Brouillard-Coyle and M. Gallant, "Primary School Action for Better Health: 12-18 Month Evaluation,” University of Windsor, Windsor, 2004.

[79] E. Maticka-Tyndale, J. Wildish and M. Gichuru, "QuasiExperimental Evaluation of a National Primary School HIV Intervention in Kenya," Evaluation and Program Planning, Vol. 30, No. 2, 2007, pp. 172-186. doi:10.1016/j.evalprogplan.2007.01.006

[80] S. C. Kalichman, L. C. Simbayi, R. Vermaak, D. Cain, S. Jooste and K. Peltzer, "HIV/AIDS Risk Reduction Counseling for Alcohol Using Sexually Transmitted Infections Clinic Patients in Cape Town, South Africa," Journal of Acquired Immune Deficiency Syndrome, Vol. 44, No. 5, 2007, pp. 594-600. doi:10.1097/QAI.0b013e3180415e07

[81] V. Mathiti, L. C. Simbayi, S. Jooste, Q. Kekana, X. P. Nibe, L. Shasha, P. Bidla, P. Magubane, D. Cain, C. Cherry and S. Kalichman, "Development of an HIV Risk Reduction Counseling Intervention for Use in South African Sexually Transmitted Infection Clinics," Journal of Social Aspects of HIV/AIDS, Vol. 2, No. 2, 2005, pp. 267-733.

[82] L. C. Simbayi, S. C. Kalichman, D. Skinner, S. Jooste, D. Cain, C. Cherry, V. Mathiti, R. Dlakulu, N. Unddermans, V. Bruinders, C. Jacobs, R. Van Wyk, C. Arendse, J. Croome and W. Bok, “Theory-Based HIV Risk Reduction Counseling for Sexually Transmitted Infection Clinic Patients in Cape Town, South Africa," Sexually Transmitted Diseases, Vol. 32, No. 12, 2004, pp. 727-733. doi:10.1097/01.olq.0000145849.35655.f1

[83] F. E. Okonofua, P. Coplan, S. Collins, F. Oronsaye, D. Ogunsakin, J. T. Ogonor, J. A. Kaufman and K. Heggenhougen, "Impact of an Intervention to Improve Treatment-Seeking Behavior and Prevent Sexually Transmitted Diseases among Nigerian Youth,” International Journal of Infectious Diseases, Vol. 7, No. 1, 2003, pp. 61-73. doi:10.1016/S1201-9712(03)90044-0

[84] J. A. Kelly, Y. A. Amirkhanian, E. Kabakchieva, S. Vassileva, T. L. McAuliffe, W. J. DiFranceisco, R. Antonova, E. Petrova, B. Vassilev, R. A. Khoursine and B. Dimitrov, "Prevention of HIV and Sexually Transmitted Diseases in High Risk Social Networks of Young Roma (Gypsy) Men in Bulgaria: Randomized Controlled Trial," British Medical Journal, Vol. 333, 2006, pp. 1098-1101. doi:10.1136/bmj.38992.478299.55

[85] C.-H. Lou, B. Wang, Y. Shen and E.-S. Gao, "Effects of a Community-Based Sex Education and Reproductive Health Service Program on Contraceptive Use of Unmarried Youths in Shanghai,” Journal of Adolescent Health, Vol. 34, No. 5, 2004, pp. 433-440. 
doi:10.1016/j.jadohealth.2003.07.020

[86] A. S. Erulkar, L. I. A. Ettyang, C. Onoka, F. K. Nyagah and A. Muyonga, "Behavior Change Evaluation of a Culturally Consistent Reproductive Health Program for Young Kenyans,” International Family Planning Perspectives, Vol. 30, No. 2, 2004, pp. 58-67. doi: $10.1363 / 3005804$

[87] C. R. Pearson, M. A. Micek, J. M. Simoni, P. D. Hoff, E. Matediana, D. P. Martin and S. S. Gloyd, "Randomized Control Trial of Peer-Delivered, Modified Directly Observed Therapy for HAART in Mozambique," Journal of Acquired Immune Deficiency Syndrome, Vol. 46, No. 2, 2007, pp. 238-244. doi:10.1097/QAI.0b013e318153f7ba

[88] C. R. Pearson, M. A. Micek, J. M. Simoni, E. Matediana, D. P. Martin and D. S. S. Gloyd, "Modified Directly Observed Therapy to Facilitate Highly Active Antiretroviral Therapy Adherence in Beira, Mozambique,” Journal of Acquired Immune Deficiency Syndrome, Vol. 43, No. S1, 2006, pp. S134-S140. doi:10.1097/01.qai.0000248339.82567.17

[89] I. S. Speizer, B. O. Tambashe and S. P. Tegang, “An Evaluation of the 'Entre Nous Junes' Peer Educator Program for Adolescents in Cameroon,” Studies in Family Planning, Vol. 32, No. 4, 2001, pp. 339-351. doi:10.1111/j.1728-4465.2001.00339.x

[90] R. J. Hayes, J. Changalucha, D. A. Ross, A. Gavyole, J. Todd, A. I. Obasi, M. I. Plummer, D. Wight, D. C. Mabey and H. Grosskurth, "The MEMA kwa Vijana Project: Design of a Community Randomized Trial of an Innovative Adolescent Sexual Health Intervention in Rural Tanzania,” Contemporary Clinical Trials, Vol. 26, No. 4, 2005, pp. 430-442. doi:10.1016/j.cct.2005.04.006

[91] A. I. N. Obasi, B. Cleophas, D. A. Ross, K. L. Chima, A. Gavyole, M. L. Plummer, M. Makokha, B. Mujaya, J. Todd, D. Wight, H. Grosskurth, D. C. Mabey and R. J. Hayes, "Rationale and Design of the MEMA kwa Vijana Adolescent Sexual and Reproductive Health Intervention in Mwanza Region, Tanzania,” AIDS Care, Vol. 18, No. 4, 2006, pp. 311-322. doi:10.1080/09540120500161983

[92] M. L. Plummer, D. Wight, A. I. N. Obasi, J. Wamoyi, G. Mshana, J. Todd, B. C. Mazige, M. Makokha, R. J. Hayes and D. A. Ross, “A Process Evaluation of a School-Based Adolescent Sexual Health Intervention in Rural Tanzania: the Mema kwa Vijana Programme," Health Education Research, Vol. 22, No. 4, 2007, pp. 500-512. doi:10.1093/her/cyl103

[93] D. A. Ross, J. Changalucha, A. I. N. Obasi, J. Todd, M. L. Plummer, B. Cleophas-Mazige, A. Anemona, D. Everett, H. A. Weiss, D. C. Mabey, H. Grosskurth and R. J. Hayes, "Biological and Behavioural Impact of an Adolescent Sexual Health Intervention in Tanzania: A CommunityRandomized Trial,” AIDS, Vol. 21, No. 14, 2007, pp. 1943-1955. doi:10.1097/QAD.0b013e3282ed3cf5

[94] E. G. Bing, K. G. Cheng, D. J. Ortiz, R. E. Ovalle-Bahamón, F. Ernesto, R. E. Weiss and C. B. Boyer, "Evaluation of a Prevention Intervention to Reduce HIV Risk among Angolan Soldiers," AIDS and Behavior, Vol. 12, No. 3, 2008, pp. 384-395. doi:10.1007/s10461-008-9368-2
[95] N. Murray, N. Toledo, X. Luengo, R. Molina and L. Zabin, "An Evaluation of an integrated Adolescent Development Program for Urban Teenagers in Santiago, Chile,” Focus on Young Adults, Washington DC, 2000.

[96] V. Toledo, X. Luengo, R. Molina, T. Molina and R. Villegas, "Impacto del Program de Educatión Sexual: Adolescencia Tiempo de Decisions,” Sogia, Vol. 7, No. 3, 2000.

[97] D. E. Morisky, C. Nguyen, A. Ang and T. V. Tiglao, "HIV/AIDS Prevention among the Male Population: Results of a Peer Education Program for Taxicab and Tricycle Drivers in the Philippines," Health Education and Behavior, Vol. 32, No. 1, 2005, pp. 57-68. doi:10.1177/1090198104266899

[98] M. A. Lightfoot, R. Kasirye, W. S. Comulada and M. J. Rotheram-Borus, "Efficacy of a Culturally Adapted Intervention for Youth Living with HIV in Uganda," Prevention Science, Vol. 8, No. 4, 2007, pp. 271-273. doi:10.1007/s11121-007-0074-5

[99] M. J. Rotheram-Borus, D. Swendeman, W. S. Comulada, R. E. Weiss, M. Lee and M. Lightfoot, "Prevention for Substance-Using HIV-Positive Young People,” Journal of Acquired Immune Deficiency Syndrome, Vol. 37, No. S2, 2004, pp. S68-S77. doi:10.1097/01.qai.0000140604.57478.67

[100] M. Kagimu, E. Marum, F. Wibwire-Mangen, N. Nakyanjo, Y. Walakira and J. Hogle, "Evaluation of the Effectiveness of AIDS Health Education Interventions in the Muslim Community in Uganda," AIDS Education and Prevention, Vol. 10, No. 3, 1998, pp. 215-228.

[101] M. Kamenga, M. Sweat, I. De Zoysa, G. Dallabetta, T. Coates, O. Grinstead, et al., "The Voluntary HIV-1 Counseling and Testing Efficacy Study: Designs and Methods," AIDS and Behavior, Vol. 4, No. 1, 2000, pp. 5-14. doi:10.1023/A:1009528505965

[102] The Voluntary HIV-1 Counselling and Testing Efficacy Study Group, "Efficacy of Voluntary HIV-1 Counseling and Testing in Individuals and Couples in Kenya, Tanzania, and Trinidad: A Randomised Trial,” Lancet, Vol. 356, No. 9224, 2000, pp. 103-112. doi:10.1016/S0140-6736(00)02446-6

[103] J. Kim, C. Watts, J. Hargreaves, L. Ndhlovu, G. Phetla, L. Morison, et al., "Understanding the Impact of a Microfinance-Based Intervention on Women's Empowerment and the Reduction of Intimate Partner Violence in South Africa,” American Journal of Public Health, Vol. 97, No. 10, 2007, pp. 1794-1802. doi:10.2105/AJPH.2006.095521

[104] P. M. Pronyk, J. C. Kim, T. Abramsky, G. Phetla, J. R. Hargreaves, L. A. Morison, C. Watts, J. Busza and J. D. Porter, "A Combined Microfinance and Training Intervention Can Reduce HIV Risk Behaviour in Young Female Participants," AIDS, Vol. 22, No. 13, 2008, pp. 1659-1665. doi:10.1097/QAD.0b013e328307a040

[105] K. F. Ford, B. D. Reed, D. N. Wirawam, P. Muliawan, M. Sutarga and L. Gregoire, "The Bali STD/AIDS Study: Human Papillomavirus Infection among Female Sex Workers,” International Journal of STD \& AIDS, Vol. 14, No. 10, 2003, pp. 681-687. 


\section{doi:10.1258/095646203322387947}

[106] K. F. Ford, D. N. Wirawan, B. D. Reed, P. Muliawan and R. Wolfe, "The Bali STD/AIDS Study: Evaluation of an Intervention for Sex Workers," Sexually Transmitted Diseases, Vol. 29, No. 1, 2002, pp. 50-58. doi:10.1097/00007435-200201000-00009

[107] X. Li, B. Wang, X. Fang, R. Zhao, B. Stanton, Y. Hong, B. Dong, W. Liu, Y. Zhou, S. Liang and H. Yang, "Short-Term Effect of a Cultural Adaptation of Voluntary Counseling and Testing among Female Sex Workers in China: A Quasi-Experimental Trial," AIDS Education and Prevention, Vol. 18, No. 5, 2006, pp. 406-419. doi:10.1521/aeap.2006.18.5.406

[108] M. Muñoz, K. Finnegan, J. Zeladita, A. Caldas, E. Sanchez, M. Callacna, et al., "Community-Based DOTHAART Accompaniment in an Urban Resource Poor Setting," AIDS and Behavior, Vol. 14, No. 3, 2010, pp. 721-730. doi:10.1007/s10461-009-9559-5

[109] T. L. Patterson, B. Mausbach, R. Lozada and H. StainesOrozco, "Efficacy of a Brief Behavioral Intervention to Promote Condom Use among Female Sex Workers in Tijuana and Ciudad Juarez, Mexico,” American Journal of Public Health, Vol. 98, No. 11, 2008, pp. 2051-2057. doi:10.2105/AJPH.2007.130096

[110] S. A. Strathdee, B. Mausbach, R. Lozada, Staines-Orozco, S. J. Semple, D. Abramovitz, M. Fraga-Vallejo, A. de La
Torre, H. Amara, G. Martinez-Mendizabal, C. MagisRodriguez and T. L. Patterson, "Predictors of Sexual Risk Reduction among Mexican Female Sex Workers Enrolled in a Behavioral Intervention Study,” Journal of Acquired Immune Deficiency Syndrome, Vol. 51, No. S1, 2009, pp. S42-S46. doi:10.1097/QAI.0b013e3181a265b2

[111] A. M. Villarruel, Y. Zhou, E. C. Gallegos and D. L. Ronis, "Examining Long-Term Effects of Cuite-A Sexual Risk Reduction Program in Mexican Youth,” Revista Panamericana de Salud Publica, Vol. 27, No. 5, 2010, pp. 345-351. doi:10.1590/S1020-49892010000500004

[112] J. S. Zhou, K. L. Zhang, L. L. Zhang, J. X. Kang, J. X. Zhang, W. H. Lai, L. Liu, G. Liu and Y. L. Zeng, “A Quasi-Experimental Study on a Community-Based Behaviour Change Programme among Injecting Drug Users in Sichuan, China,” International Journal of STD \& AIDS, Vol. 20, No. 2, 2009, pp. 125-129. doi:10.1258/ijsa.2008.008145

[113] J. R. F. Lau, R. Wang, H. Chen, J. Gu, J. Zhang, F. Cheng, L. Zhang, H. Y. Tsui, N. Wang, Z. Lei, X. Zhong and Y. Lan, "Evaluation of the Overall Program Effectiveness of HIV-Related Intervention Programs in a Community in Sichuan, China," Sexually Transmitted Diseases, Vol. 34, No. 9, 2007, pp. 653-662. doi:10.1097/01.olq.0000260948.10572.b9 